\title{
Risk Aversion in the Board Room. An Analytical Approach on Corporate Governance of German Stock-Listed Companies
}

\section{Knut Michelberger}

University of Latvia, Faculty of Economics and Management, Department of International Economics and Business, Aspazijas blvd. 5, Riga, Latvia

Гross

According to the agency theory, a positive relationship between company performance and good corporate governance should exist. A broader study of the author of this paper examines a sample of German stock-listed companies whereas Germany can be seen as one of the most highly regulated countries concerning corporate governance. The overall purpose of the author's study is to analyze the effect of supervisory board characteristics and procedures on firm performance. Several corporate governance variables such as number of committees, board independency, supervisory board compensation, personal risk liability, etc. are examined regarding their effects on firm performance in terms of firm growth and profitability. Two different approaches were selected: (1) a quantitative data analysis, based on financial figures and corporate governance variables, and (2) a survey of supervisory board members out of this sample. The total sample consists of 128 German stock-listed companies. The financial data are obtained from the financial databases providers ThomsonOne and Morningstar. The corporate governance data are also collected from annual reports and from corporate governance compliance statements. According to the German Corporate Governance Codex (DCGK) each stock-listed company has to explain their compliance with the DCGK rules. Thus, the DCGK represents a benchmark of good corporate governance and allows collecting objective and comparable quantitative data to estimate the corporate governance level. The main data analysis methods are bivariate analysis and tests for statistical differences (t-test), the latter in particular to find differences between groups clustered by their 5-years total shareholder return (TSR) growth resulting in a TSR top-30 group and TSR bottom-30 group. While the fulfilment of good corporate governance standards over all shows no significant effect on firm performance, this paper focusses on the findings that risk aversion in the board room is increasing as a result of governance regulations and that growth outperformers have a lower degree of risk aversion. It is concluded that an own-risk deductible in the D\&O insurance policy leads to risk-averse supervisory board behavior and thus to lower TSR growth.

KEYWORDS: Corporate Governance; Supervisory Board; Principal-Agent Theory; Risk Aversion; Firm Performance.

\section{Abstract}

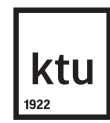

European Integration Studies No. 10/ 2016 pp. 135-144

DOI 10.5755/j01.eis.0.10.16191 (C) Kaunas University of Technology 
The failure of several corporations such as Enron, Tyco, Parmalat, Skandia, Lehman Brothers, etc. in the last decade shows that firms should undertake additional modifications in their corporate governance (CG) to increase transparency and to assure shareholders' reliance on management (Hermalin \& Weisbach, 2012, p. 326). A large consensus exists among both academics and professionals that new efforts are important to improve corporate governance practices to protect the shareholders' interests and to stabilize market economy basics, due to the fact that many scholars, economic analysts, and corporate practitioners have linked the severity and increasingly circular nature of financial and economic crises to corporate governance failures (Sun, Stewart, \& Pollard, 2011, p. 1; Gupta, Chandrasekhar, \& Tourani-Rad, 2013 , p. 86). Although several corporate governance codices are introduced in many countries, they are not legally binding but provide recommendations for good corporate governance. The term 'corporate governance' summarizes efforts to optimize a company's management system and its monitoring. The concept is based mainly on the agency theory and the problem of information asymmetries. The agency theory's essence is the separation of management and monitoring. Today, corporate governance defines the regulatory framework for management and supervision of companies. Good corporate governance should ensure and guide a responsible, professional, and transparent business administration in the interest of owners and external stakeholders. Characteristics of 'good' corporate governance are regulations concerning appropriate risk management, procedures, management organization, long-term value creation, transparency, safeguarding mechanisms to secure the interests of stakeholders, and, overall, a clearly defined control structure. The German government passed the Law of Control and Transparency (KonTraG) in 1998 which was one of the first corporate governance laws worldwide. According to Section 161 of the German Stock Corporation Act the German Corporate Governance Code applies for all listed companies. The supervisory and executive boards of corporations are obliged to explain annually whether the Code is adopted or rejected as a whole or only in parts. Insofar, in the German Case, an objective benchmark exists to qualify and to examine the several dimensions of 'good' corporate governance. The field of study of the author's thesis is the effect quality of the German 'good' corporate governance model on firm performance and total shareholder return. The research problem is whether the German model is relevant for serving the shareholder's interest. According to Jensen \& Meckling (1976), a positive relationship between company performance and 'good' corporate governance should exist which is also assumed in general by recent research, while other researchers doubt that the highly-regulated European corporate governance models and particularly the German corporate governance model are really serving effectively the shareholders' interests. This issue is examined based on a sample of 128 largest German stock-listed companies constituting the research object. The aim of the author's thesis is to analyze the relationship between essential parts of the German Corporate Governance Model with firm performance of German listed companies and to identify elements with positive and negative effects. To reach this aim, literature review of high-rated academic journals and research publications as well as prior empirical research identified factors, variables and a research design leading to a 13 factors- model developed by the author. The data for these 13 factors are collected by the author through the analysis of 256 annual reports of 128 companies and through a database query to collect data on company financials. Additionally, 30 expert interviews with supervisory board members of 15 top-performing and 15 non-performing companies are conducted to get deeper insights into the qualitative (structural and processual) aspects of supervisory board activities and the required competence. The quantitative data are analyzed by means of bivariate correlation analysis, tests for statistical differences (t-test) and multiple regression 
analysis. While the author's study provides empirical evidence that main elements of the German Corporate Governance procedures and regulations are irrelevant for shareholders and stakeholders or is even against their interests, this paper focuses on the results relative to risk aversion in the board room.

Governance is a historic term for the description, evaluation, and comparison of state governance. The term stood linguistically 'in competition' with the term government, and was as such often used as a synonym for government in political literature. However, the term governance was increasingly less used in the political context in the 20th century (Van den Berghe, 1999, pp. 220-221). However, in the 1970s, the concept of governance revived in American business language through the concept of corporate governance with the focus on corporate responsibility. A decade later, the World Bank introduced the term good governance and thus coined this phrase (Wouters \& Ryngaert, 2005, p. 72). Today, corporate governance defines the regulatory framework for the management and supervision of companies. The corporate governance framework is largely determined by legislators and owners (Spira, 2002, p. 11), whereas the actual corporate governance design is the supervisory board's responsibility. The company-specific corporate governance system consists of the totality of relevant laws, regulations, codes, letters of intent, mission statement, and management habits, and monitoring (OECD, 2010, p. 34). However, there is still no common understanding or a single definition of what exactly corporate governance means or covers (Stiglbauer, 2010, p. 9). Academic literature discusses good corporate governance and the improvement of existing corporate governance. Good corporate governance should ensure and guide a responsible, professional, and transparent business administration in the interest of owners, but also of external stakeholders (i.e., creditors, sales and procurement markets, society, citizens) (Spedding, 2009, pp. 500-503). Discussed characteristics of 'good' corporate governance are (1) appropriate risk management, (2) formal and transparent procedures for the proposal and election of board members, (3) functional organizational management, (4) management decisions focused on long-term value creation, (5) transparency in internal and external corporate communications, (6) safeguarding mechanisms to secure the interests of various groups (stakeholders), and, overall, (7) a clearly defined management and control structure (Passenheim, 2010, p. 11). Governance relies on its effectiveness for the transparency of financial information and the transparency of management decisions so that external 'market' mechanisms can be effective through disciplinary effects on the company. In addition to these external market monitoring mechanisms, the agency theory discourse has shaped the internal boardroom reform (Bratton, 2012, p. 102). Perhaps the most significant contribution in this context came in the form of the widespread adoption of performance-based executive compensation schemes (Bratton, 2012, pp. 111-115), which follows directly from the assumption that the executives self-interest must be aligned with the shareholders' interests, for example, through value-based key performance indicator systems, rewarding an increase of added economic value, etc. (Zarbafi, 2011, pp. 61-63). The subject of 'good' corporate governance has gained in importance also in Germany since the 1990s. The German Government passed the Law of Control and Transparency (KonTraG) in 1998, which was the first actual corporate governance law in Germany, which extended the liability of directors, supervisors and auditors. The core of this law is a provision forcing companies to introduce and operate company-wide early warning systems and to publish statements about risks and the company's risk structure in a special report attached to the annual report. In 2000, the federal government set up a government commission on the modernization of company law, due to the bankruptcy of one of Germany's largest construction companies. Among other things, this commission recommended develop-

\section{The 'Theory' of Corporate Governance}


ing a 'Best Practice Code' for German companies. For this end, the 'Government Commission on the German Corporate Governance Code' was formed as a self-regulation measure of the economy in 2001. The Commission is funded by the private sector and completely independent in their decisions. The government cannot give instructions for the design of the Code. (Jannott \& Frodermann, 2014, pp. 266-268). The Commission does not include any representative of the government or politics and released the "German Corporate Governance Code" in 2002. Due to the subsequent publication in the Federal Law Gazette the declaration obligation in Section 161 in the Stock Corporation Act applies for listed companies. The supervisory and executive boards of corporations are obliged annually to explain if the Code is adopted as a whole or only parts of the Code are followed (so-called qualified deviation explanation or selection solution). (Jannott $\&$ Frodermann, 2014, pp. 266-268).

The declaration must be made permanently available to the shareholders and all other interested parties on the company's website. The German Corporate Governance Codex (DCGK) is a reaction to the criticisms of the German corporate 'constitution' expressed particularly from international investors such as, for example, the lack of transparency, as well as inadequate focus on shareholder interests and of board professionalism, diversity, and independence. The aim is also to unify and standardize measures concerning the fulfillment of 'good' corporate governance (Rode, 2009, p. 110). The question remains which are the essential elements of 'good' corporate governance. Here, the empirical research in this field should provide some answers.

\section{Prior empirical research}

This section analyzes the state of empirical research on the relation of good corporate governance and firm performance with respect to single parameters of corporate governance such as board size, role duality, independent directors and firm performance. The Sarbanes-Oxley Act can be seen as a turning point after which in many countries a lot of changes can be observed. Many countries have introduced corporate governance codes as a kind of soft law since 2002. In addition, laws were modified with regard to the requirement to supervisory boards in many countries. In this respect, the post-Sarbanes-Oxley period is characterized by a strong transnational standardization of corporate governance requirements. Whereas the pre-Sarbanes-0xley period was characterized by significant differences between companies in terms of corporate governance both between companies within a country and between companies of different countries, the post-Sarbanes-Oxley period is characterized by a cross-country homogenization of corporate governance codes and practices (Bainbridge, 2016, p. 90, p. 269).

Dalton et al. stated in a meta-analysis of empirical studies that both the supervisory board composition (insider/outsider proportion) as well as leadership structure do not have any effect on financial performance (Dalton, Daily, Certo \& Roengpitya, 1998, p.282). Since then, further studies have been published which come to different results. Overall, a positive effect of corporate governance on firm performance must be assumed. However, the number of studies which determine no or a negative impact is not negligible. Most of the studies do not use a standardized general measure to define good corporate governance. They measure single aspects of a corporate governance system such as the leadership structure (Castaner \& Kavadis, 2013), board ownership (Carline et al., 2009), or board independence (Nicholson \& Kiel, 2007) and their impact on firm performance. Some studies determine a relationship between only two variables, such as financial performance with board or management structures (Krivogorsky, 2006). The findings of such studies with a reduced set of variables are mostly that a single aspect of corporate governance has a positive impact, others not. Brenes et al., for example, determine that the more intensive the evaluation of management performance by the board is the better is the company performance to vis-à-vis competitors (Brenes, Madrigal \& Requena, 2011, p. 282). Nicholson \& Kiel 
show that an "independent board" has a positive impact on firm performance (Nicholson \& Kiel, 2007). Others, such as Bauer et al. (2004), Larcker et al. (2007), Bhagat and Bolton (2007), Daines et al. (2008), Renders, Gaeremynck, \& Sercu (2010), and Gupta, Chandrasekhar \& Tourani-Rad (2013), use corporate governance rankings to compare the corporate governance 'culture' of countries, in which companies are embedded, with the overall performance of companies in this country. Thus, they are not interested in measuring the impact of single aspects of corporate governance of company performance. Some studies use a very small sample. Only Bauer et al. (2004), Brown \& Caylor (2006), Bhagat \& Bolton (2007), Daines et al. (2008), Renders, Gaeremynck \& Sercu (2010), and Gupta, Chandrasekhar \& Tourani-Rad (2013) use samples with more than 250 companies. Taking this into account, the ratio between studies stating a positive impact and studies with neutral or negative impact shows a relatively balanced ratio. Additionally, most studies examine only short time periods from two to four years. Only Gompers et al. (2001) examine a longer time period (from 1990 to 1999). Therefore, it seems to be questionable if such short-term studies really measure what they pretend to measure. In recent years, further studies are published concerned the effect of corporate governance on firm performance. Due to the growing formalization through country-specific codification the problem of comparability of results arises. Consequently, one-country approaches are preferred. Thus, Conheady et al. (2015) examines only Canadian listed-companies, Fuzi et al. (2016) focuses only on Malaysian listed companies, Rose (2016) on Danish and Akbar et al. (2016) on British companies. Concerning the German Corporate Governance Code and its effect on firm performance, only a few empirical studies were published in the last five years. Stiglbauer (2010) has examined a set of 113 companies from the DAX30, TecDax, MDAX and SDAX regarding firm-specific characteristics. He argues that the implications of his study are valid for all German listed companies. He has measured firm performance in terms of profitability using the return on assets (ROA), total shareholder return (TSR) and return on equity (ROE). Stiglbauer (2010, p. 4) mentions six prior studies examining the effect of corporate governance on firm performance among German companies whereas all these studies have an observation period prior to 2005 which is three years after the introduction of the first version of the German Corporate Governance Code. Stiglbauer (2010), however, has not examined the effect of single corporate governance characteristics and their cumulative effect on firm performance. Ebeling (2015) has examined the implementation degree of the corporate governance code and its effect on firm value among companies of the German Real Estate Index (DIMAX) including 75 companies with an observation period of just a single year (2010).

According to § 161 German Corporate Governance Codex (DCGK), each stock-listed company must issue an annual statement concerning the company's compliance with the German Corporate Governance Codex (DCGK). This declaration must contain the number and reasons for the exceptions explicitly. . Thus, the DCGK represents a benchmark of 'good' corporate governance and allows collecting quantitative and comparable data to estimate corporate governance level without any subjective factors such as researcher classifications. Good corporate governance is observed mainly by deviations from the 'good' corporate governance codex as a benchmark provided by the German Corporate Governance Codex and is measured as total number of exceptions from the codex and as exceptions from selected core elements of the codex. The German Corporate Governance Codex (DCGK) comprehends 62 sections. Only a certain number of sections are selected, which are to be seen as essential parts of 'good' corporate governance, based on the factors derived from the literature and empirical research provided by the author. For the purpose of this paper, $\S 3$ of the DCGK, $\S 3.8$ of the DCGK, and $\S 5$ of the DCGK (Division

\section{Research Approach, Data and Methods}


of Supervisory Board 'Labor' regulating the duties) are of special focus. $\S 3$ of DCGK regulates the cooperation between the executive management and supervisory board. However, $99 \%$ of the counted exceptions of this sample refer only to $\S 3.8$. This section rules the own-risk deductible included in the directors and officers liability insurance (D\&O insurance). DCGK requires: "If the company buys $D \& O$ insurance for the board, a deductible of at least $10 \%$ of the damage must be agreed up to at least a half times the fixed annual remuneration of the board member. In $D \& 0$ insurance for the supervisory board, a similar deductible must be agreed upon." (DCGK, 2015) The ruling idea behind $\S 3.8$ of DCGK is to increase the liability of board members so that board members are, on the one hand, more risk averse and, on the other hand, exercise more caution in their supervisory activities. Additionally, board size, number of committees, compensations, etc. are collected as well. Some data are calculated based on given financials, such as share of management costs to revenue.

The total sample consists of 128 German companies listed in the DAX30, MDAX, SDAX, and TecDAX in the period 2005 to 2014 for which the necessary data were completely available. The data source for firm performance metrics is Thomson ONE by Thomson Reuters and Morningstar. The data for qualifying corporate governance are retrieved from corporate governance reports, containing the declaration of exceptions to the Corporate Governance Codex, and annual reports containing key performance metrics, the number of board members, board members' academic degrees, number of committees, performance-based supervisory board compensation, etc. The values are collected from the annual reports and corporate governance compliance statements for the years 2010 and 2014, converging with the financial data that refer on a 5-year period such as 5-year total shareholder return average, 5-year return growth (CAGR) ${ }^{1}$, etc. The financial data are all scaled numerically, as are most corporate governance values.

However for this purpose, only some data are nominally scaled. The sample is, particularly in comparison with international key figures, a representative sample. However, it must be mentioned that the sample is dominated by smaller companies due to the fact that already two indices are small companies' indices, namely the SDAX and TecDAX. The TecDAX is not defined by a market cap threshold, but by segment definition. The sample's revenue median is EUR $1,765 \mathrm{~m}$ so that $50 \%$ of the companies generate lesser than EUR $1,765 \mathrm{~m}$. Instead, the top quartile includes companies from EUR 14,534m up to EUR 202,445m. Additionally, 109 companies generate lesser than $20 \%$ of the revenue of the top company, which is Volkswagen AG with EUR 202,458m. However, from the shareholder's view, the sample is very profitable with the total sample's 5 -year total shareholder return (TSR) average of $21.8 \%$. Furthermore, the sample shows a significantly higher year-over-year growth rate in 2014 than the S\&P 500 . Whereas the sample's average is $10.3 \%$, the S\&P 500 year-over-year revenue growth is 2.83\% (CSIMarket 2015).

The research process involves several steps and different statistical tests conducted with the total sample as well as with subgroups. The main data analyses methods are bivariate correlations testing and tests for statistical differences (t-test), the latter in particular to find differences between groups clustered by their 5 -year total shareholder return growth resulting in a TSR top-30 group and TSR bottom-30 group.

Based on these data, which are supplemented by several firm performance characteristics such as revenue growth, total shareholder growth, and financial leverage, the following tests are applied:

1 CAGR: Compound Annual Growth Rate. 
1 Testing Statistical Influence of Single Board Characteristics on Firm Performance among the Total Sample. The main data analysis applies Pearson's R as a correlation coefficient to analyze bivariate correlations or cumulative influences of corporate governance characteristics on firm performance through the application of the multivariate regression analysis.

2 Testing Differences between TSR Performance Groups: Additionally, not only bivariate correlations among the total sample are analyzed but also among different groups. The sample is clustered into two different groups. One group, which is named TSR top-30 group (TSR outperformers), includes the top-30 companies with the highest total shareholder returns among the total sample, while the second group, which is named TSR bottom-30 group (TSR underperformers), includes the 30 companies with the lowest total shareholder returns in a 5-year period among the total sample. Both groups are compared by applying a t-test, to determine the significance of group differences, while among both groups, the same tests are performed as with the total sample regarding bivariate correlations.

3

Testing Multivariate Effects among the Total Sample: All independent corporate governance variables are included in the final testing to examine their cumulative impact. The multivariate test is conducted to test the influence of the accumulated effects of all corporate governance variables on the total shareholder return (TSR).

While the group statistics of the TSR-30:30-sample indicates that the TSR top-30 companies have smaller supervisory boards, fewer committees and smaller executive boards, pay smaller supervisory board compensations and executive board compensations, but comply lesser with the DCGK ("Number of Except. § 161") than the TSR bottom-30 companies, the TSR top-30 group shows a 5 -year TSR growth of 38\% against -8\% among the TSR bottom-30 group. Furthermore, the TSR top-30 group shows a double 5-year revenue growth compared with the TSR bottom-30 group. Reviewing the changes in the exceptions to the above mentioned rules, it is obvious that the total number of exceptions have not changed significantly. The most significant changes are measured in three different areas: The number of exceptions concerning the D\&O own-risk deductible ("\# Excep. DCGK § 3") decreased by 28\%, while the number of exceptions concerning the link between corporate performance and supervisory compensation (“\# Excep. DCGK § 5.4.6 Sec. 2 ") decreased by $24 \%$. Instead, the number of exceptions concerning the independence of supervisory members ("\# Excep. DCGK § 5.4.2") increased by 125\%, however, starting from a low base level. Thus, it can be determined that the sample's companies increased the subsequent risk for supervisory activities and tied the supervisory compensation more closely to firm performance. Instead, the board structure characteristics regarding the committees and the overall structure of cooperation between executive board and supervisory board, the independence of members, etc. remained more or less on the same level. Therefore, it can be stated that the regulatory intentions 'good' corporate governance are increasingly met by the sample's companies. These observations have been also confirmed by the multivariate regression analysis performed on the total sample. The multivariate test is executed with the control variables revenue growth, ROIC, and firm size (revenue 2014 in EUR mil.), because the bivariate tests have indicated that, for example, the number of committees, the number of exclusions, etc. also depend, at least partly, on firm size (in revenue 2014 in EUR mil.). The model summary shows that the exception from DCGK $\S 3$ is the only variable explaining TSR growth. As mentioned above, this exception results in at least $99 \%$ from exceptions to $\S 3.8$. This section rules that an own-risk deductible should be included in the directors and officers liability insurance ( $D \& 0$ insurance) with the objective to increase risk-taking costs. However, the results of the multivariate test do not explain the direction of influence. Therefore, the question remains regarding whether the absence or the existence of 
an own-risk deductible influences firm performance in the sense of a causal relationship. The t-test descriptive statistics show that 70 companies of the total sample declare non-compliance with $\S 3.8$ while 57 companies have concluded a D\&O insurance contract containing an own-risk deductible. The comparison of the group with $D \& O$ insurance contracts containing an own-risk deductible and the group without the own-risk deductible reveals that the group without risk-sharing agreements perform better with a TSR growth of $18 \%$ while companies with risk-sharing show considerably lower TSR growth of 8.7\% (t-test group statistics). The group differences are highly significant with $p 0.002$ (independent sample test). Thus, it may be concluded that the own-risk deductible leads to risk-averse supervisory board behavior and thus to lower TSR growth. However, on the other hand, it must be noted that this factor has only a low explanatory power regarding the total shareholder return growth, as the results of the multivariate regression analysis has shown.

\section{Conclusions}

The results of all bivariate analysis of the total sample indicate that none of the single factors show a higher $(r>0.5)$ and significant correlation with firm performance indicators. Therefore, it can be concluded that the selected parameters of 'good' corporate governance are not significantly relevant for revenue growth and total shareholder return growth. However, this does not mean that they are irrelevant. The examination of the TSR-30:30-sample indicates that the TSR top-30 companies - with the TSR growth of 38\% - have smaller supervisory boards, fewer committees and smaller executive boards, pay smaller supervisory board compensations and executive board compensations, but comply lesser with the DCGK ("Number of Except. § 161 ") than the TSR bottom-30 companies with the TSR growth of $-8 \%$. The higher the number of exceptions to 'good' corporate governance, the higher the firm performance and the degree of shareholder interest fulfillment in terms of TSR growth and revenue growth. Furthermore, the multivariate regression analysis indicates that although the cumulated influence of all variables is negligible, the issue of risk sharing of the supervisory board measured by the number of the exceptions to DCGK $\S 3.8$ regulating the own-risk deductibles for supervisory board members leads to risk-averse supervisory board behavior and thus to lower TSR growth. In this sense, it can be concluded that the increase of governance regulation should not be continued to avoid serious disadvantages, particularly in the form of decreasing risk-taking tolerance.

\section{References}

Akbara, S., Poletti-Hughesa, J., El-Faitourib, R., \& Shahc, S. Z. A. (2016). More on the relationship between corporate governance and firm performance in the UK: Evidence from the application of generalized method of moments estimation. Research in International Business and Finance, 38, 417-429. http://dx.doi.org/10.1016/j.ribaf.2016.03.009

Bainbridge, S. M. (2016). Corporate Governance After the Financial Crisis. Oxford: Oxford University Press.

Bauer, R., Gunster, N., \& Otten, R. (2004). Empirical evidence on corporate governance in Europe: The effect on stock returns, firm value, and performance. Journal of Asset Management, 5, 91-104. http://dx.doi.org/10.1057/palgrave.jam.2240131

Bhagat, S. \& Bolton, B. (2008). Corporate gover- nance and firm performance. Journal of Corporate Finance, 14, 257-273.

http://dx.doi.org/10.1016/j.jcorpfin.2008.03.006

Bloomberg (2015).German Government Bonds. Retrieved from http://www.bloomberg.com/markets/rates-bonds/government-bonds/germany [06.11.2015]

Bratton, W. (2012). Agency theory and incentive compensation. In R. S. Thomas, J. S. Beasley, \& J. G. Hill (eds.), Research Handbook on Executive Pay (pp. 101-122). Northampton: Edward Elgar http://dx.doi.org/10.4337/9781781005101.00011

Brenes, E. R., Madrigal, K., \& Requena, B. (2011). Corporate governance and family business performance. Journal of Business Research, 64, 280-285. http://dx.doi.org/10.1016/j.jbusres.2009.11.013 
Brown, L. D. \& Caylor, M. L. (2006). Corporate governance and firm valuation. Journal of Accounting and Public Policy, 25, 409-430. http://dx.doi.org/10.1016/j.jaccpubpol.2006.05.005

Castaner, X. \& Kavadis, N. (2013). Does Good Governance prevent bad strategy? A study of corporate governance, financial diversification, and value creation by French corporations, 2000-2006. Strategic Management Journal, 34, 863-876. http://dx.doi.org/10.1002/smj.2040

Carline, N. F., Linn, S. C., \& Yadav, P. K. (2009). Operating performance changes associated with corporate mergers and the role of corporate governance. Journal of Banking, \& Finance, 33, 1829-1841 http://dx.doi.org/10.1016/j.jbankfin.2009.03.012

CISMarket (2015). S\&P 500 Financial Strength Information. Retrieved from http://csimarket.com/ Industry/industry_Financial_Strength_Ratios. php?\&hist=1 [06.11.2015]

Conheady, B., Mcllkenny, P., Opong, K. K., \& Pignatel, I. (2015). Board effectiveness and firm performance of Canadian listed firms. The British Accounting Review, 47(3), 290-303.

http://dx.doi.org/10.1016/j.bar.2014.02.002

Dalton, D. R, Daily, C. M., Certo, S. T., \& Roengpitya, R. (1998). Meta-Analyses of Financial Performance and Equity: Fusion or Confusion? Strategic Management Journal, 19, 269-290. http://dx.doi.org/10.1002/ (SICI)1097-0266(199803)19:3<269::AID-SMJ950>3.0.CO;2-K

Daines, R., Gow, I., \& Larcker, D. (2008). Rating the ratings: How good are commercial governance ratings? Journal of Financial Economics (JFE), 98(3), 439-461. http://dx.doi.org/10.1016/j.jfineco.2010.06.005

Ebeling, P.-C. (2015). Corporate Governance kapitalmarktorientierter Immobiliengesellschaften (Schriften zu Immobilienökonomie und Immobilienrecht. Regensburg: International Real Estate Business School

Gupta, K., Chandrasekhar, K., \& Tourani-Rad, A, (2013). Is corporate governance relevant during the financial crisis? Journal of International Financial Markets, Institutions and Money, 23, 85-110. http://dx.doi.org/10.1016/j.intfin.2012.10.002

Fuzi, S. F. S., Halim, S. A. A., \& Julizaerma, M.K (2016). Board Independence and Firm Performance. Procedia Economics and Finance, 37, 460-465. http://dx.doi.org/10.1016/S2212-5671(16)30152-6
Gompers, P., Ishii, J., \& Metrick, A. (2003). Corporate governance and equity prices. Quarterly Journal of Economics, 116(1), 107-155. http://dx.doi.org/10.1162/00335530360535162

Hermalin, B. E. \& Weisbach, M. S. (2012). Information disclosure and corporate governance. Journal of Finance, 67, 195-234. http://dx.doi.org/10.1111/j.1540-6261.2011.01710.x Jannott, D. \& Frodermann, J. (2014). Handbuch der Europäischen Aktiengesellschaft. Heidelberg: C. F. Müller. Janocha, M. (2014). Vergütung mittels Bonusbanken: Eine agency-theoretische Perspektive. Gabler: Wiesbaden. http://dx.doi.org/10.1007/978-3-658-06300-9

Jensen, M. C. \& Meckling, W. H. (1976). Theory of the Firm: Managerial Behavior, Agency Costs and Ownership Structure. Journal of Financial Economics, 3(4), 305-360. http://dx.doi.org/10.1016/0304405X(76)90026-X

Krivogorsky, V. (2006). Ownership, board structure, \& performance in continental Europe. The International Journal of Accounting, 41(7), 176-197.

http://dx.doi.org/10.1016/j.intacc.2006.04.002

Larcker, D., Richardson, S., \& Tuna, I. (2007). Corporate governance, accounting outcomes, and organizational performance. The Accounting Review, 82, 963-1008. http://dx.doi.org/10.2308/accr.2007.82.4.963

Nicholson, G. J. \& Kiel, G. C. (2007). Can Directors Impact Performance? A case-based test of three theories of corporate governance. Corporate Governance, 15(4), 585-608.

http://dx.doi.org/10.1111/j.1467-8683.2007.00590.x

OECD (2010). Corporate Governance Accountability and Transparency: A Guide for State Ownership, Brussels: OECD.

Passenheim, O. (2010). Enterprise Risk Management. London: Ventus.

Renders, A., Gaeremynck, A., \& Sercu, P. (2010). Corporate Governance and Performance: Controlling for Sample Selection Bias and Endogeneity. Corporate Governance, 18(2), 87-106.

http://dx.doi.org/10.1111/j.1467-8683.2010.00791.x

Rode, O. (2009). Der deutsche Corporate-Governance-Kodex: Funktionen und Durchsetzungsmechanismen im Vergleich zum britischen Combined Code. Frankfurt: Lang.

Rose, C. (2016). Firm performance and comply or explain disclosure in corporate governance. European Management Journal, 34(3), 202-222

http://dx.doi.org/10.1016/j.emj.2016.03.003 
Spedding, L. S. (2009). The Due Diligence Handbook: Corporate Governance, Risk Management and Business Planning, Burlington: CIMA Publishing.

Spira, L. (2002). The Audit Committee: Performing Corporate Governance. New York: Kluwer.

Stiglbauer, M. (2010): Corporate Governance Berichterstattung und Unternehmenserfolg: Eine empirische Untersuchung für den deutschen Aktienmarkt. Wiesbaden: Springer Gabler. http://dx.doi.org/10.1007/978-3-8349-8629-0

Sun, W., Stewart, J., \& Pollard, D. (2011). Introduction: rethinking corporate governance - lessons from the global financial crisis. In W. Sun, J. Stewart \& D. Pollard (eds.), Corporate Governance and the Global Financial Crisis: International Perspectives (pp. 1-22). Cambridge: Cambridge University Press. http://dx.doi.org/10.1017/CB09780511736599.001

Van den Berghe, L. (1999). International Standardisation of Good Corporate Governance. New York: Springer. $h$ ttp://dx.doi.org/10.1007/978-1-4615-5185-0

Wouters, J. \& Ryngaert, C. (2005). Good Governance: Lessons from International Organizations'. In D. Curtin \& R. A. Wessel (eds.), Good Governance and the European Union: Reflections on Concepts (pp. 69-102). Antwerp: Intersentia.

Zarbafi, E. M. (2011). Responsible Investment and the Claim of Corporate Change: A Sensemaking Perspective. Wiesbaden: Springer http://dx.doi.org/10.1007/978-3-8349-6202-7

\section{About the author \\ KNUT MICHELBERGER \\ Dipl. Ökonom, Dipl. Ing. \\ of International Economics and Business \\ Fields of research interests \\ Corporate Governance \\ Address \\ Aspazijas blvd. 5, Riga, Latvia \\ Tel. +411622681417 \\ E-mail: knut.michelberger@kmgib.com}

University of Latvia, Faculty of Economics and Management, Department 